\title{
What's Right About Rights?
}

\author{
fames Allan*
}

The end of the Second World War, with its massive violations and obscenities, together with the new-found influence of the United States and its 200 year old constitution, has heralded or spawned a new era for rights - more particularly the discussing of politics and morals in terms of the concept of rights. Although first conceptualized by the ancient Greeks, rights had their theoretical heyday in the 17th century; they had their revolutionary heyday in the 18th century; and then they were eclipsed by 19 th century movements, either utilitarian or idealist, which could not or would not accommodate them. Today they are again the major, perhaps the sole, currency of moral and political debate throughout the world. This paper will attempt critically to assess the validity of such a tendency.

What then are rights? Rights are not things. One may not find them floating in the atmosphere, either visible or invisible. Nor are they sensations in the mind. To answer this question one must realize that the primary job of most legal words, ${ }^{\prime}$ for example, 'liability', 'onus', 'right', 'duty', or 'negligence', is not to stand for or describe anything in the material or psychological world. Rather it is to describe a function. Accordingly, one ought not to abstract any such legal word from the sentence in which its full function can be seen. To elucidate a legal word best, look at the whole statment in which it has its characteristic use. Thus asking " When is it accurate to say that one has a right to do or to refrain from something?" " is a much more apt formulation than asking "What are rights?" or simply discussing 'rights". The former question does not presuppose that rights are things and therefore

* Lecturer in Law, City Polytechnic of Hong Kong. The author wishes to acknowledge the influence, generally, of Jeremy Bentham, David Hume and H.L.A. Hart on what follows.

1. See H.L.A. Hart's "Definition and Theory in Jurisprudence" (1953) Inaugural Lecture, Oxford, at 70L.Q.R. (1954) or Essays in furisprudence and Philosophy (1983, Clarendon Press), pp. 21-48. In this article Hart asserts that the common mode of definition largely fails with respect to the law as legal words do not have the straightforward connection with counterparts in the world of fact which ordinary words have (e.g. , 'trees', 'cancer', 'soccer'). Most words are defined by placing them in a larger category and then differentiating them from other things in that category (genus et differentia). Such a mode of definition breaks down in the legal realm, indeed in the whole non-material realm, because nothing 'corresponds' to legal words. 
avoids obfuscation. ${ }^{2}$ By more precisely posing a question one may eliminate some of the vagueness surrounding rights.

Yet if rights are not to be defined in the same way as things are, how shall they be understood? Hohfeld ${ }^{3}$ and Bentham ${ }^{4}$ understood that legal relationships are correlative. There cannot be rights in a vacuum. Firstly there must be rules. Rules lay down obligations or duties which are linked or correlated to rights. How can anyone have a right where no person or body has a corresponding duty? Hollow and empty would any such right be. Thus Hohfeld reduces all legal relationships into a limited number of terms. A duty becomes "I must". A right becomes "others must". A power becomes "I can". An immunity becomes "others cannot". And a privilege becomes "I may". ${ }^{5}$ Each relates to and depends on the others. A right, therefore, is to be understood in terms of whether the corresponding duty shall be performed or not. It may be thought of as an expectation guaranteed by legal rules.

This foray into linguistics is to warn against treating abstract concepts as real things; they are not. 'Fictitious entities' (e.g. 'inflation' or 'gravity') are man-made mental constructions used to help us categorize, label and understand a vast and nearly ungovernable experiential world. ${ }^{6}$ Their 'existence' depends on the active powers of the mind operating through language. Indeed the limits of language sometimes force us to resort to fictitious entities. Such fictions ${ }^{7}$ in language are perfectly permissible if necessary and if speakers realize fictions are human creations without an independent existence. Legitimate fictions make discussion possible; illegitimate fictions mystify and reify.

Language also has the power to command through the emotive connotations of many words. ${ }^{8}$ Frequently words are non-neutral and carry suggestions of emotional attitudes. Thus, to characterize another's opinions as 'reactionary', 'socialist', 'liberal', or 'Marxist' is to use a word which carries the extra baggage of 'good' or 'bad'. It closes off debate, relying on the passions rather than reason. Likewise, depending on the point of view favoured, alternatives such as 'assassinated-summarily executed', 'eloquent-bombastic', 'courageous-reckless'

2. As Bentham and Hart were aware, "though theory is to be welcomed, the growth of theory on the back of definition is not": ibid., p.41. That is to say, one ought to avoid the need for theorizing simply because of the way words are defined and used. Only in trying to answer "What is a right?" rather than explaining it does one need theory. Other examples of this at a practical, though trite, level are given by Robert Thouless in Straight and Crooked Thinking 7th ed. (1963, Pan Books Ltd.), Ch. 5.

3. See W. N. Hohfeld's, Fundamental Legal Conceptions as Applied in fudicial Reasoning (1946).

4. See Jeremy Bentham's, Works (Bowring edition, 1838-1843) especially his Fragment on Government therein.

5. In working with Hohfeldian simplifications one must be alert that, like all insightful simplifications, a degree of common sense is needed to avoid distortion and misapplication.

6. In a sense language is paradoxical - its labels and categories are unduly confining and distorting and yet without language how could we think at all?

7. Bentham first articulated a theory of fictions, in inchoate form, in his early work An Introduction to the Principles of Morals and Legislation: see,e.g. , Burns and Hart's edition, pp.53 (footnote), 97, 101-2, $114-5,125$ inter alia.

8. See Thouless, supra n.2, Ch.1. 
or 'generous-extravagant' can be used to describe the same factual reality.

In discussing rights, therefore, both the above linguistic dangers are to be avoided. Firstly, we must understand rights functionally - linked as they are to duties and pre-supposing some sort of rules. Secondly, we must not allow emotive language to sway us, in and of itself. There is a tendency today to 'demand one's rights'. This may be in part because the word 'right' carries a non-neutral meaning; it has the notion of 'good' appended to it. To give someone his or her rights must be good; to refuse bad. One potential danger inherent in succumbing uncritically to such an appeal is that the ensuing proliferation of rights-claims may debase the whole currency of rights. Tacitly all rights are then brought down to the level of the least valid claim. So let us proceed to consider the validity and desirability of political and moral debate being discussed in the language of rights while keeping in mind that clear thinking requires an awareness of the deficiencies and the power of language.

Throughout his life Jeremy Bentham made the point that talk of natural rights is simple nonsense; talk of natural and imprescriptible rights, rhetorical nonsense "nonsense upon stilts". 9 What did he mean? By simple nonsense Bentham was making the purely logical point that rules and systems precede rights. Rights are something man adds to the world, not something he finds in it - some sort of gift of nature. Rights must follow rather than precede the establishment of systems (i.e. government) and rules. No rights, therefore, can exist anterior to civil society.

As early communities formed and grew more complex 'rules', or more accurately 'modes of resolving and preventing disputes', ${ }^{10}$ sprang up to allow for the smoother operating and greater security of the group. These rules grew up slowly by custom and habit. "With the rules were attached obligations and duties on specific members and groups in the body politic. In turn, with the duties on some came corresponding rights to others.

Of course many people do not share this view of the evolution or origin of rights. Some hold to the view that there are indeed non-legal rights, ${ }^{12}$ or rather natural rights which attach to all human beings - presumably by reason of their being humans. Such a view, generally speaking, sees 'rights' not as human artefacts, not as dependent on social conventions or social recognition for their existence, but as

9. See Bentham's Anarchical Fallacies and The Rationale of fudicial Evidence, both in the Bowring edition (1838-1843) of his Works.

10. Karl Llewellyn's 'Law-Jobs Theory' was that there are certain needs that must be met for a human group to survive as a group and to achieve the purposes for which it exists. Conflict and the divisive side of human nature threatens group survival. Thus conflict-prevention and conflict-resolution (the "law-jobs") are a necessary pre-condition of group survival and effectiveness: see Llewellyn, "The Normative, the Legal and the Law Jobs", 49 Yale L.F. (1940) 1355 as well as The Cheyenne Way (with Hoebel and recently re-printed by the University of Oklahoma Press).

11. See David Hume who throughout his writings (e.g., A Treatise of Human Nature, Essays) emphasized the influence and impact of habit and custom on human reason and human affairs. On this and other matters Bentham owed a debt to Hume (see, inter alia, Halevy, The Growth of Philosophic Radicalism 2nd ed. (1952).

12. See, e.g., Ronald Dworkin, Taking Rights Seriously (Duckworth, N.Y., 1978). On the question of 'moral' rights, as opposed to 'natural' or 'human' rights, see infra. 
reflective of certain features of human nature. Thus this theory makes rights objective and assigns them on the basis of 'natural' criteria. It must select some set of basic rights most congruent with natural facts. To the query, "Which natural facts?", the response must involve some set of the facts of human nature. Of course this reasoning, strictly speaking, limits the range of rights to humans and only humans. ${ }^{13}$ It also makes whatever set of rights is ultimately chosen as being congruent with human nature one that is eternal; homo erectus, the Greek slave, the serf of the Middle Ages and the ante-bellum black slave, all being humans, have and did have the same rights as any citizen of New York, London or Tokyo (albeit the former may not have been aware of their rights nor have had those rights as well protected). Context is irrelevant to this analysis. Choose those aspects of 'humanness' that give rise to certain rights and everything else must follow; now, in the past, and in the future, regardless of any other factors. And which specific aspects of human nature give rise to these rights? Is it our God-given soul? This presumes much, lacks a scientific foundation, and raises more questions than it answers. Is it our ability to reason? Presumably then, somewhere along the course of evolution, once a creature has the ability to reason it suddenly acquires a full complement of eternal rights (or at least rights lasting until the species loses the ability to reason). And this is true even if that creature is unaware of its rights; even if the whole world is unaware of its rights; even if the creature is not human.

Such natural rights theories seem to fly in the face of experience. This is the more noteworthy as most adherents of the position put it forward as a descriptive, not merely prescriptive, theory. Yet only in the most abstract of senses, if at all, can it be said that all humans possess the same rights, even in today's world. Most people presently existing are not able to claim these many rights supposedly due to them 'as humans'. How can one possibly assert that Roman slaves did have the right to free speech or that Persian captives did have the right not to be sold as slaves by their Greek captors or that many of today's Cambodians, Vietnamese or even Aborigines do have the right to liberty, to happiness, to free speech or even to life? Such talk is meaningless, simple nonsense. Bentham was right because he saw that this sort of parlance in terms of rights is criterionless, a mere expression of faith.

There are others who defend non-legal rights on a different ground altogether, on the basis of a social contract. What rules and rights for social living would people accept, or might they have accepted, if they set aside subjective biases and

13. It is submitted that one of the practical limitations of 'rights discourse' is here exemplified with reference to animal welfare concerns. Forcing those concerned with the plight of animals to conduct their dialogue in terms of natural rights, or human rights, not only clouds the essential point that animals should never be made to suffer more than we, as humans, have determined to be absolutely necessary - which, in itself, leaves open the question why humans should have this power. It also suggests that animals, as non-human species, perhaps lack certain of mankind's 'inherent' rights; the unspoken, indeed ineffable, conclusion being that their unnecessary suffering may be justifiable. Conversely talk in terms of 'animal rights' forces proponents to the verge of saying that all living beings have rights by virtue of being alive. Experience, not to mention most dinner plates, shows that such claims are nowhere respected. Is talk in such terms helpful or useful? 
formed a detached judgement on the question? One is asked to imagine ${ }^{14}$ a fictitious negotiation, a priori, in which humans, not knowing what their future position or status in the society will be, reach a unanimous agreement on what rights and distributions all of them will enjoy. We are told they can reach this agreement based on principled self-interest and reason. Given certain premises that all reasonable beings would surely accept $(e . g$. , that with one's future place in the hierarchy uncertain, everyone would choose the fullest degree of liberty applicable to all as well as the greatest possible distribution of wealth which did not unduly hamper productivity), ${ }^{15}$ one can move deductively to a set of rules - and therefore rights - to govern society. But how can it be said that $a$ priori, or even in the light of experience, there are any premises on which every self-interested person would agree? Does this mesh with our experience of the diversity of human nature? Does this presume rationality and if so why? And, moreover, why is it in fact irrational to take chances on one's future, particularly if one has calculated the odds and they appear favourable? Are liberty and self-respect really, a priori, to be preferred over wealth and material comforts? Surely there are no universally agreed premises from which anything further can be deduced. Thus if social contract theory is defensible at all it ought really to be couched in terms of majorities, with all the attendant difficulties that brings with it. ${ }^{16}$

Even if, somehow, unanimity could be achieved in some big meeting taking place before time itself, why should the rules and rights formulated by the forefathers bind forever the progeny? This type of justification for non-legal rights throws responsibility for today's binding 'agreements' back onto those who came. before today, rather than making those actually in the society responsible for how it is set up. It lays the foundation for these rights by invoking the notion of 'justice', based on some unreal negotiation, when it is far from clear or uncontroversial what justice is or how it can usefully be employed.

"To invoke justice is the same thing as banging on the table: an emotional expression which turns one's demand into an absolute postulate. That is no proper way to mutual understanding. It is impossible to have a rational discussion with a man who mobilises 'justice', because he says nothing that can be argued for or against. His words are persuasion, not argument. The ideology of justice leads to implacability and conflict ... . it precludes all rational argument and discussion of a settlement."17

14. See John Rawls, $A$ Theory of Justice (Oxford University Press, 1973) for the most recent formulation of this approach where purportedly neutral people, unaware of the empirical world and their future place in it, strike a deal behind a so-called 'veil of ignorance'. The seminal works on social contract theory belong to Locke and Rousseau.

15. Because, it is said, rational, self-interested people behind a veil of ignorance would not take chances with their future lot.

16. Unscientific talk and speculation of majority preferences tend to wreak of the personal preferences of the speaker.

17. Alf Ross, On Law and fustice (1958), pp.274-75. 
Lastly, and perhaps most tellingly, social contract theory is suspect because no such negotiation about rights and distributions ever took place! Thus a fiction has been introduced by the adherents of this theory. But why is a fiction needed? Rules and rights grew up gradually, by custom, habit, trial and error, as humans slowly organized into ever larger and more complex social systems to capitalize on the benefits for security, production, and defence that communal living brings. Why resort to a fiction, in this instance a prevarication, when the facts do not require it? Fictions are properly used to help categorize and conceptualize experience, not to fly in its face.

So if the warrant for the existence of non-legal rights, either in the form of natural rights theories or social contract theories, seems unconvincing then where is one left? Moreover, is it possible that an ideology, such as that surrounding natural rights, might be illogical or indefensible on strictly rational grounds and yet productive of much good? Do 'natural rights' and 'social contract' theories sow doubts which may reap a subsequent harvest of the outright rejection of all rights-based claims?

The notion of rights this paper propounds conceives of a right as a man-made concept, a human artefact, which may be used to promote chosen ends, for example to create greater societal harmony or fairness. This is a welfare linked, consequentialist view of rights. Admittedly many people view rights and utility as antithetical, combatants filled with mutual anathema, on the ground that pursuing the general welfare inevitably means doing so at the expense of individuals. Yet if it could be shown that enforcing certain prescribed rights is desirable and promotes selected goals of general welfare better than permitting the unchecked pursuit of goals or policies, ${ }^{18}$ there would be no conflict. All conceptions of rights, either legal or non-legal, have in common the notion that rights act as constraints on the pursuit of goals. Thus it is, for example, that the right to free speech may occasionally clash with governmental policies aimed at greater social and racial harmony. How then can it be said that the existence of rights could better promote certain general welfare goals? The answer is paradoxical. The goals and policies of human beings and their institutions are sometimes, perhaps often, mistaken or flawed. Knowing this to be true it is quite justifiable to curb a government's unqualified pursuit of ends or goals. It is a recognition of mankind's, or reason's, limitations. Were we omniscient and infallible it would be rational never to obstruct, in any way, the pursuit of goals leading to greater general welfare. But we recognize our limitations, leading to a rational irrationality of sorts. Experience of our species' failings leads to the awareness that recognizing certain rights - or constraints on the pursuit of general goals - will produce more welfare than if those rights were not recognized. Their recognition will, on the whole, sufficiently limit errors and produce security and fairness to outweigh the possible success of well-intentioned policies. On this view, we should talk in terms of and adopt

18. That this is possible depends on the perception of human nature as neither inherently bad nor inherently good as well as a recognition that irrationality has some role in affairs human. 
certain rights because they enhance the functioning of society or reduce the risk of it going awry. We adopt a rights approach even though we know these specified rights will sometimes over-rule policies designed for, and potentially productive of, the general welfare. Nevertheless, our received wisdom has taught us that our society is better off by providing for certain rights. ${ }^{19}$ Such rights may be illogical, in that they block policies which are intended for society's benefit. However, knowing what we do of tyranny, ineptitude, fallibility, and even good intentions, we choose to construct certain roadblocks all the same.

This welfare based view of rights is not divorced from experience; it does not create eternal, objective rights; it does not link rights to some intangible, mysterious quality emanating from human beings; it does not rely on fictitious agreements between fictitious people which bind real people in real circumstances; it may deliberately tie the hands of some of its officials in their pursuit of efficiency but it does this when experience shows that a particular society is better off in the long haul with certain officials having one hand tied behind their backs; it does not indulge in 'cultural imperialism' by imposing, under the guise of universal abstractions, the standards of one society on a differently developed society; it allows one, at least partially, to taste the overpowering draught of a belief in rights without waking up with a hangover!

This prescriptive view of how we should envisage and utilize rights and rightsterminology meshes well with our historical and empirical understanding. It recognizes that rules develop first with communal living. Such rules in some way provide for obligations and concomitant rights. As a particular social group evolves so too do the rules that keep it together and thus the attendant obligations and rights. Such a view of rights need not say there are only legal rights. It simply denies that there are the criterionless, so-called 'natural' or 'human' rights. The question of whether 'moral rights' might exist is left open. All that is demanded is that somehow moral rules be established first. If the view is taken that there are valid moral rules, either to which all could possibly agree ${ }^{20}$ or which flow from some moral principle, ${ }^{21}$ then Bentham's logical point - that rights pre-suppose rules and obligations - would be met.

19. This conception of rights is closely analogous to the view of democracy, not as the best possible system of government, but as the least bad; i.e., human nature being what it is, and power having a seemingly magnetic hold on rulers, democracy in this view is better than other forms of government because it allows the governed a regular opportunity to pass judgement on, even to throw out, an existing government - with all the concomitant advantages such a threat carries with it (cf. The Economist, April 23-29, 1988, special article by Karl Popper.) Such a view avoids mawkishness and undue adulation while recognizing the inefficiencies, compromises, slow reactions and short-term thinking that comes with democracy.

20. E.g., that all promises should be kept or that killing is never justified.

21. E.g., utility. However there are serious problems with basing rights conceptions on utilitarian grounds as is explored and elucidated by H.L.A. Hart in Essays on Bentham (Clarendon Press, 1982), Ch.IV, particularly pp. 84-87. 'Utilitarian entitlements' differ from what is thought of as non-legal rights because they: a) fluctuate with changing circumstances; b) signify 'ought' rather than 'must'; and c) do not create coercive sanctions. 
To turn back now to discuss Bentham's other barb - "nonsense upon stilts". ${ }^{22}$ This refers to claims that certain rights, even be they legal rights, not only exist but are absolute, imprescriptible and boast an unending, unchangeable right to exist. But how can this be? At most there could only ever be one absolute right because when two allegedly absolute rights were to clash, one would have to give way. Moreover, so called 'absolute rights' may conflict with one another, or, the same absolute right may conflict with itself in two or more different people - meaning that one party who was owed this 'absolute right' would not be able to have it enforced. On the other hand, if all rights are man-made then no-one could prescribe imprescriptibility. We may want to set high hurdles to the removing or foregoing of specific rights but to purport to forbid future legislators from ever tampering with them under any circumstances is ludicrous, "nonsense upon stilts". A theory of rights which admits that a very high degree of consensus indeed may be required to dispense with society's most valued rights is different in kind from one which purports to shout "never". The doctrine of omnipresent, inalienable rights has no place in the real world of day-to-day social living.

In his Anarchical Fallacies Bentham also asserted that appeals to natural rights are sometimes "mischievous nonsense". The "mischievous nonsense" epitaph refers to the tendency that proclamations of universal rights have in exciting the dissocial passions by providing the purported justifications for disobedience to any government or measure an individual happens not to like. By conflating 'law as it is' and 'law as it ought to be' ${ }^{23}$ declarations of universal rights confuse law and a particular version of morality, allowing 'ought' and 'ought not' to take the place of 'is' and 'is not' in respect of the binding force and effect of laws. The anarchist is thus enabled to say, "This ought not to be the law, therefore it is not, so I am free not merely to censure but to disregard it." Obversely, the reactionary is enabled to say, "This is the law, therefore it is what it ought to be and no criticism is valid."24

In conclusion, it is suggested that prescribed rights, when understood functionally and not cloaked in emotive language, do have a significant role to play in our society. What is really at stake is preventing government from abusing its powers. The question of whether talk of natural rights is illogical and yet has been productive of good in human affairs - and what such an admission would signify is left for some future time. In any event, today's tendency to conduct all moral and political discourse in the lingua franca of rights is misplaced. As Bentham said: "Reasons for wishing there were such things as rights are not rights: a reason for wishing that a certain right were established is not that right - want is not supply hunger is not bread." 25

\section{Supra, p.3.}

23. See Hart, Essays in furisprudence and Philosophy, supra n.2, Essay 2, "Positivism and the Separation of Law and Morals", for an excellent defence of the distinction.

24. Ibid, p.53 cf. Introduction to the Principles of Morals and Legislation, Concluding Note, paragraphs 26 and 27.

25. Works II, 501 . 
Doubtless the current predominance of rights will ebb in the course of time. What the cause of that decline will be one would not hazard to predict. Perhaps America, that great moralizing nation and most enthusiastic embracer of the language of rights, will lose its foremost world position to countries with a more Asian, less individualistic perspective. Perhaps a new Utopian ideology or collectivism or community-ism will attract sufficient adherents. Marx himself rejected rights because he saw that they pre-supposed a conflict between the individual and the collective - an unacceptable presupposition in any Utopian world view - and because he believed that abstract equality at the level of 'rights' merely concealed the real economic power structure. Again, perhaps Liberalism will continue its retreat. Classic liberalism and the debate of political and moral questions in terms of rights are closely interwoven. Both are founded on presumptions of rationality, individualism and progress (i.e., the U.S. world-view writ large). Today these three presumptions are under attack on all sides. Finally, perhaps a cynicism will come to the fore and it will be asked what 'rights' have given the vast majority born into subjection and poverty, not freedom of any real kind.

If there be an eventual lessening in the importance of rights terminology, one hopes that a clear understanding of the logic and functioning of rights will preserve their benefits so that only the excesses are lost. In the meantime, it must be admitted that in most Western societies today it is power-conferring to be able to claim a right. Indeed, in the West it is still the ideal language in which ethnic minorities and women can express their claims. All the same, though, it is counter-productive to speak solely in terms of rights. Far too many people today speak and act, even think, as though rights were things; as though rights could exist before and without corresponding rules and duties; as though all rights were absolute and imprescriptible; as though rights were given mankind, with his soul, by God; as though it were never misleading to inject rights terminology into every debate; and as though all these misconceptions could not possibly infect an otherwise healthy and useful tool. 